\title{
WOODEN SHIPS AND WOODEN CARGOES - A REMINISCENCE OF MORBIDITY ${ }^{1}$
}

\author{
BY W. R. HADDOW
}

\author{
Department of Lands and Forests, Totonto, Ontario
}

$\mathrm{D}$

URING THE late war many small wooden boats were built in Canada and the United States for naval service. These included mine sweepers, sub-chasers, P.T. boats, patrol boats, net tenders, sea-going tugs, aircraft retrievers, aircraft refueling boats and numerous others. It has been said of those vessels that wooden construction was used in them not only on account of the prevailing shortage of steel, but because wood was better adapted to the severe service requirements. Nevertheless, the liability of wood to decay was recognized as a serious shortcoming which required special consideration; and a recently published paper ${ }^{2}$ (which lists in its bibliography some thirty-odd references to additional studies) describes research conducted in the United States during the war with a view to preventing the occurrence and spread of decay in wooden ships.

Similarly, it will be recalled that during the first world war other fleets of wooden vessels were blueprinted and launched. The famous "Victory" ships, hurriedly built to meet a critical requirement of shipping, are remembered not altogether happily; for they had a number of defects, not the least of which was their notorious destructibility by rot. At that time, too, the problem of decay in timber cargoes, especially of wood from the Pacific Coast which was destined for aircraft construction in the United Kingdom, obtruded itself-a matter which, in various forms, has continued to occupy the attention of research workers to the present day.

Actually, this story of decay in ships' timbers and timber cargoes is a very old one indeed-doubtless as old, even, as wooden ships. But, to be sure, it is recorded only in part; and as evidenced by the history of the last two wars, it was during periods of great activity in naval construction, naturally enough, that the longest and most morbid chapters of it were written. At such times, one suspects, materials and methods were used under pressure which were not entirely in accord with the best conservative practice in shipbuilding. It is interesting and instructive to recall a chapter of this story, now largely forgotten, which relates to the history of Canada and to what was for a long time its principal commerce, namely the export of square timber.

Although masts, and oak and pine timber were exported from Canada long before the British conquest, the great development of the Canadian timber trade may be said to have begun with the nineteenth century. It was greatly stimulated at first by the deliberate policy of protection against Baltic timber,

1.The factual matter concerning the early Canadian timber trade used in this article was drawn from official public papers comprised in the "Imperial Blue Books on Affairs Relating to Canada" and especially from the "First Report (relative to the Timber Trade) from the Select Committee of the House of Lords Appointed to Enquire in to the Means of Extending and Securing the Foreign Trade of the Country .... July, 1820"

2. Tippo, Oswald, James M. Walter, Silas J. Smucker, William Sparkman Jr. The effectiveness of certain wood preservatives in preventing the spread of decay in wooden ships. Lloydia $10 ; 3$. $175-208,1947$.
Lleness 
which had long supplied the British market. Duties on Baltic timber originally imposed for war revenue were soon consolidated with protection duties designed to foster the Canadian trade; and by 1819 Baltic timber was paying $£ 3 / 5$ per load ${ }^{1}$ (plus three shillings if brought in foreign ships), while colonial timber was free. Small wonder that enterprising merchants shipped Baltic timber to Pictou, Nova Scotia, whence they returned it to the British market as colonial produce! The Government soon assessed a duty of ten shillings against colonial timber; but it was many years before the differential was reduced to approximate the unequal shipping costs as between Baltic and British North American ports. This differential was maintained not only because of fiscal considerations, but primarily to encourage the colonial industry for political reasons. And encouragement was required because the wood goods market, traditionally a conservative one, considered that colonial timber was much inferior to Baltic timber. The principal objection to colonial timber was its alleged liability to rot.

For the same reason red pine, and especially "pitch" 2 pine, were long favoured over white or yellow pine in the British market, and commanded higher prices. True, red pine timber more nearly approached in character the commercial varieties of Baltic and Scandinavian "fir" which had been familiar for centuries in the British trade; but red pine, too, was generally considered to be twice as durable as white or yellow pine, which was plagued by a bad reputation for rot.

The extent of this prejudice which, alas, under the circumstances seems largely to have been justified, is suggested in part by the opinion of one John White, a timber merchant, who before a commission of enquiry in 1820 said that on account of its poor quality not a stick of North American timber would be used in Britain except for the duties protecting it. There was no opportunity for testing the validity of that opinion; but rot or no rot, there was a remarkable growth of the North American timber trade under protection, as evidenced by the fact that the number of ships engaged in it rose from eighty in 1801 to eight hundred in 1820; in which year 307,813 loads of British American timber were imported into Britain, as against 65,841 loads from the Baltic. From the year 1808, British American and especially Canadian timber continued to supply the bulk of British imports. In that year, for the first time, the Baltic trade was surpassed; and although the level of the latter was generally maintained, in spite of fluctuations, it only occasionally ever exceeded in volume the growing trade from the colonies.

The tremendous industrial and building boom initiated in London and other British cities towards the close of the eighteenth century demanded enormous quantities of timber. Concurrently, the needs of an expanding merchant marine and of the greatest navy in the world had to be filled. Ship. building became the largest wood consuming industry. But for that use, as for most others, Baltic and North European timber, both oak and "fir", was generally preferred to the colonial product. Even for masts, a preference was often shown for Baltic timber, or for "pitch" pine. The largest single sticks,

1. One load equals $50 \mathrm{cu}$. ft. of squared timber.

2 "Pitch" pine comprised Atlantic hard pines, including Pinus rigida. 
of course, could be had only in white pine from the colonies; but in the construction of large composite masts the use of North American timber was confined principally to the spindle and checks. The complaint against colonial timber was that it deteriorated rapidly from rot; and for that reason it was excluded from the naval dockyards from time to time. That there was good reason for such discrimination can scarcely be doubted. The following table is of interest in showing cause for dissatisfaction on the part of the navy with North American timber. Its substance was given in evidence, relative to the timber trade, before an investigating committee of the House of Lords in the year 1820 .

In the light of the above it is not surprising that Sir Robert Seppings, one of the Commissioners of the Navy Board, considered that the oak and fir timber of Canada was only half as durable as Baltic timber. According to him ... "it is particularly liable to the growth of fungi, that species of vegetation which is the forerunner of dry rot." He said that the navy had suffered very considerably from the introduction of Canadian timber; and in consequence they had entirely discontinued the use of it in the fabric of ships. It was employed only as masts and deals. When a piece of Canadian timber was brought in contact with English timber, or indeed that of any other country, it caused the growth of fungi in that other adjoining timber. A particular instance of such effect was shown in the repairs which had been recently made to H.M.S. "Devonshire" of 74 guns, the bottom of which was planked with oak timber from Canada. In many places the material next that timber, to within half-an-inch of the outer surface, was completely decomposed and reduced to snuff.

Other witnesses reported similarly. Thus the "Queen Charlotte", built at Deptford of Canadian "fir" and oak, was said to have been rotten before she came out of dock.

The opinion of merchant ship owners was just possibly a little more favourable towards colonial timber. Mr. Bateman believed that Canadian red pine was generally considered to be intrinsically of good quality, though it was not thought to be as durable as Baltic timber. In conversion it suffered a much greater loss, too. Mr. Metcalfe said that yellow pine was used chiefly for decks, sheathing, cabin work, bulkheads and masts. He claimed that for decking it was better than Baltic timber, which would not stand the sun. He had even pulled up a deck of Baltic fir and replaced it with yellow pine which, he said, was generally preferred for that purpose in Liverpool. Decks of $21 / 2^{\prime \prime}$ yellow pine deals were practically sound after twenty-four years. As for masts, the "Amity" of South Shields, 219 tons, built in 1801, had lower masts of Quebec pine. The main mast was in for sixteen years and was finally injured by accident. The foremast was in for nineteen years, when it was found decayed under the rigging.

In the common timber trade of London, North American timber was recognized as softer, less durable, and "every description of it more liable to dry rot than timber from North Europe." The red pine, however, was dis, tinguished from white or yellow pine by its greater durability. The soft white 
Table Showing the Durability of Frigates built of North European Fir ${ }^{1}$ and 2uebec Red and Yellow Pine.

\begin{tabular}{lccc} 
Ship"s Name & $\begin{array}{c}\text { No. of } \\
\text { Gung }\end{array} \quad$ When Launched & $\begin{array}{c}\text { When rendored } \\
\text { onfit for service }\end{array}$ & $\begin{array}{c}\text { Approximate } \\
\text { of yearu } \\
\text { Service }\end{array}$ \\
\hline
\end{tabular}

1. Timber Growth of North Europe

$\begin{array}{lrrl}\text { Maidstone } & 32 & \text { 12 } \text { December, 1795 } \\ \text { Shannon } & 32 & 9 \text { February, 1796 } \\ \text { Clyde } & 38 & 26 \text { March, 1796 } \\ \text { Tamar } & 38 & 26 \text { March, 1796 } \\ \text { Glenmore } & 36 & 24 \text { March, 1796 } \\ \text { Trent } & 36 & 24 \text { February, 1796 } \\ \text { Circe } & 32 & 17 \text { November, 1804 } \\ \text { Pallas } & 32 & 17 \text { November, 1804 } \\ \text { Hebe } & 32 & 31 \text { December, 1804 } \\ \text { Jason } & 32 & 21 \text { November, 1804 } \\ \text { Minerva } & 32 & 25 \text { October, 1805 } \\ \text { Alexandria } & 32 & 18 \text { February, 1806 }\end{array}$

November, $1804 \quad 9$

April, $1802 \quad 6$

September, $1804 \quad 8$

August, $1802 \quad 5$

December, $1802 \quad 6$

June, $1803 \quad 7$

October, $1813 \quad 9$

Lost, $1810 \quad 5$

July, $1811 \quad 7$

October, $1814 \quad 10$

April, $1814 \quad 8$

2. Timber Growth of Canada
(a) Red Pine

$\begin{array}{llll}\text { Cydnus } & 46 & 17 \text { April, 1813 } \\ \text { Eurotas } & 46 & 17 \text { April, 1813 } \\ \text { Niger } & 46 & 29 \text { May, 1813 } \\ \text { Meander } & 46 & 13 \text { August, 1813 } \\ \text { Pactolus } & 46 & 14 \text { August, 1813 } \\ \text { Tiber } & 46 & 10 \text { November, 1813 } \\ \text { Araxes } & 46 & 13 \text { September, 1813 } \\ \text { Tanais } & 46 & 27 \text { October, 1813 } \\ \text { Tagus } & 42 & 14 \text { July, 1813 } \\ \text { Eridanus } & 42 & 1 \text { May, 1813 } \\ \text { Tigris } & 42 & 26 \text { June, 1813 } \\ \text { Ister } & 42 & 14 \text { July, 1813 } \\ \text { Scamander } & 42 & 13 \text { July, 1813 } \\ \text { Orontes } & 42 & 29 \text { July, 1813 } \\ \text { Euphrates } & 42 & 8 \text { November, 1813 }\end{array}$

(b) Yellow Pine

$\begin{array}{llll}\text { Hebrus } & 42 & 13 & \text { September, } 1813 \\ \text { Granicus } & 42 & 25 \text { October, } 1813 \\ \text { Alpheus } & 42 & 6 \text { April, } 1814\end{array}$

\begin{tabular}{ll} 
December, 1815 & 3 \\
June, 1816 & 3 \\
\hline December, 1816 & 3 \\
July, 1817 & 2 \\
September, 1818 & 3 \\
July, 1816 & 5 \\
May, 1816 & 3 \\
June, 1817 1816 & 3 \\
December, 1817 & 4 \\
August, 1818 & 4 \\
February, 1817 & 5 \\
June, 1817 & 3 \\
\end{tabular}

October, 1816

October, $1816 \quad 3$

1. "Fir" = the common European pine. 
pine was said to be preferred to any other for packing cases, carvings, mouldings, musical instruments, blinds and other objects where lightness and freedom from knots were desirable. Indeed, the manufacture of musical instruments, picture frames, window blinds, toys and pressboards used in cotton manufacture, were among the established uses of Canadian timber. Of all the deals imported from Canada one-third were used in the manufacture of packing cases and boxes.

In building construction, Canadian timber rated generally much below that from the Baltic. According to William Stewart it was acknowledged that Canada could produce satisfactory red pine; but most Canadian timber was used for inferior purposes,--for second-rate buildings and houses, and for many common uses. If, he said, he were building a mansion, he would prefer Baltic timber; but for barns, stables and other buildings of that description, Canadian timber might do.

John White said that formerly red pine of Canada had been thought good, but that it had "got out of reputation". There was a large demand for yellow pine for small houses around London, but wherever enclosed, it was much subject to dry rot.

Alexander Copland, a timber merchant and builder, said that North American timber was much inferior to that of Europe. It was soft and not durable, and liable to dry rot. It was not used in the best buildings in Lon. don, and its employment was not even allowed by Government men there. Speculative builders, however, used it. If two Canadian planks were placed together, dry rot would be found between them in twelve months; but in the case of Baltic wood, not in ten years. American pitch pine was satisfactory, though brittle. Little red pine was available. In some minor uses, such as picture frames, the carvings on church pews, etc., Canadian timber was preferred. Queried as to the relative value of a house built of Norway timber, and one built of Canadian timber, the witness said he could not recommend the purchase of the latter at all. If he were the owner of it, he would have all the wood removed and Baltic wood substituted. In his opinion Canadian timber would never be used, if the duties were equivalent, except for temporary purposes such as platforms at a coronation, or anything of that sort. (Shades of Queen Victoria!)

The cause of all this trouble with Canadian timber, both in shipbuilding and in common use, was not altogether unsuspected. Thus Henry Warburton, shipowner (and a very observant and intelligent one), after describing the ravages of rot on land and sea, gave it as his opinion that the long, wet voyage of the timber ships from Quebec, had a very deleterious effect on the quality of the cargoes. He was of opinion, too, that ships sometimes "took" the rot from the timber, which was often found to be covered all over with a white fibre. He was accustomed, on that account, to having his holds scraped, and washed with sulphate of copper to prevent dry rot; and claimed that such solution, or one of corrosive sublimate, would completely prevent rot from entering the ship from the cargo. "I am quite satisfied", he said, "that the white fungus affecting the surface of American deals and timber, is the seed of the dry rot." 
Mr. William Peraberton thought, too, that the close holds of ships brought on the dry rot; and that there was a causal connection between the presence of fungi and decay. He said it was well known that Canadian timber was much more subject to dry rot in close situations than Baltic timber. Questioned as to whether he considered dry rot . . . "the vegetation of the juice of the tree?" he replied that he believed ... "it would bear seed like any other cryptogamous plant." He thought that the secret of Mr. Kyan's patent preparation, currently sold as a protection against dry rot, was that it "poisoned the vege. tation."

It is not difficult nowadays to appreciate the hazards to both cargo and vessel, of those long voyages of the timber ships. Loaded wet, there was every opportunity for the rapid development and spread of decay during warm summer months when the customary annual voyage was made. Small wonder, indeed, if later such wood was found to develop rot in use whenever it was at all favourably placed for it!

But what a pity that so many beautiful trees have gone to the building of so many mean and troublesome houses; to the stuffing of so many rooms with ugly gimcrackery that happily has long ago been relegated almost every. where to millions of ash cans; and to the raising, so it was said, of so many flimsy platforms, which in the course of edifying spectacles doubtless often collapsed through rot, under the feet of thousands of imminent emigrants! And it is unfortunate that Canadian timber received so early, through no inherent fault of its own, a black mark which it is just possible has not yet been entirely erased. 